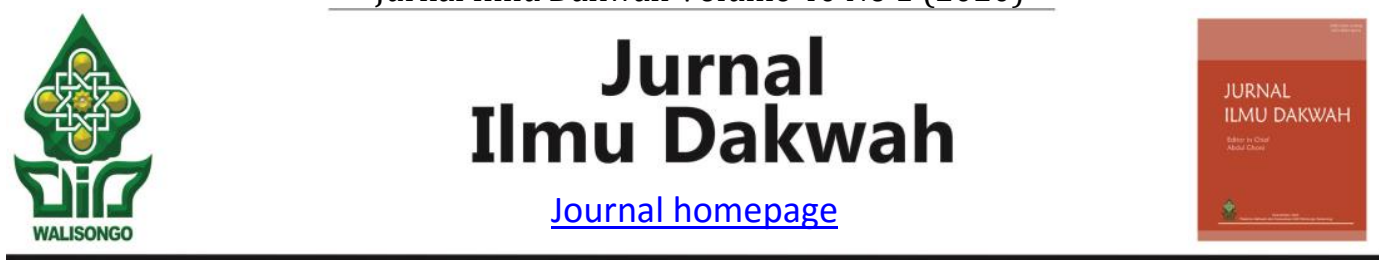

\title{
MASJID, KHUTBAH JUMAT, DAN KONSTRUKSI REALITAS KEAGAMAAN DI RUANG PUBLIK: STUDI TENTANG MATERI KHUTBAH JUMAT DI MASJID-MASJID KOTA SURAKARTA
}

\author{
Mibtadin'), Fathol Hedi2) \\ 1Institut Islam Mamba'ul Ulum Surakarta \\ Email: mibtadinanisahmad@gmail.com \\ 2Institut Islam Mamba'ul Ulum Surakarta \\ Email: fatholhedi71@gmail.com
}

\begin{abstract}
This research is about the material or sermons content in Surakarta mosques in which there is an indication of hate speech if it is viewed from the analysis discourse and its implications for the religious diversity of worshipers in each mosque. Is there an element of hate speech in sermons in several mosques in the city of Surakarta? what are the implications of the Friday sermon on the diversity of society? This research is a descriptive qualitative research, data collection is done by observation, in-depth interviews, and documentation. Data analysis was performed with interactive analysis including: data reduction, data delivery; and drawing conclusions. Sermons are words that contain religious advice and information. Sermon material serves to strengthen the religious narrative of pilgrims. In general, the Friday sermon material does not contain indications of hate speech. The implication of Friday sermons on worshipers is to provide perspective and point of view so that it will affect the religious life of worshipers so they can be tolerant and respectful to groups outside of themselves.
\end{abstract}

Keywords: Friday sermon, hate speech, religious diversity

\begin{abstract}
Abstrak
Penelitian ini mengenai materi atau konten khutbah yang ada di masjid-masjid Surakarta didalamnya ada indikasi mengandung unsur ujaran kebencian jika dilihat dari diskursus analisis serta implikasinya terhadap keberagamaan jamaah di setiap masjid. Apakah ada unsur ujaran kebencian pada khutbah di beberapa masjid a di Kota Surakarta? bagaimana implikasi khutbah Jumat terhadap keberagamaan masyarakat? Penelitian ini merupakan penelitian kualitatif deskriptif, pengumpulan data dilakukan dengan observasi, wawancara mendalam, dan dokumentasi. Analisis data dilakukan dengan interaktif analisis meliputi: reduksi data, penyampaian data; dan penarikan kesimpulan. Khutbah merupakan perkataan yang mengandung nasehat dan informasi keagamaan. Materi khutbah berfungsi untuk penguatan narasi keagamaan jamaah. Secara umum, materi khutbah Jumat yang ada tidak mengandung indikasi ujaran kebencian. Implikasi khutbah
\end{abstract}


Jumat pada jamaah adalah memberikan perspektif dan cara pandang sehingga akan berpengaruh terhadap kehidupan beragama jamaah sehingga bisa bersikap toleran dan menghargai kepada kelompok di luar dirinya.

Kata Kunci: Khutbah jumat, ujaran kebencian, keberagamaan

\section{PENDAHULUAN}

Ruang demokrasi yang terbentuk pasca runtuhnya Orde Baru telah membuka kesempatan bagi kelompok Islamis untuk mengartikulasikan kepentingan politik dan ideologi keagamaan mereka secara agresif, reaktif, dan demonstratif (Idharam, 2011: 11). Indonesia menjadi ruang publik yang pintunya terbuka dengan lebar untuk semua ideologi keagamaan untuk berkembang, termasuk ideologi Islamis. Ideologi mereka berkembang bersamaan masuknya gerakan Islam trans-nasional di Indonesia seperti yang direpresentasikan HTI, Ikhwanul Muslimin (IM), Salafi, Syiah, dan Jamaah Tablig (khuruj). Di tengah masyarakat, ideologi mereka tersosialisasikan dengan bermetamorfosis membentuk simpul baru seperti halaqoh atau kajian-kajian di masjid. Dengan menguasai masjid, mereka leluasa menyebarkan ideologi Islamismenya, termasuk dengan melakukan pengaturan khutbah jumat yakni menunjuk orang dari kelompok mereka. Selain itu, kelompok Islamis ini juga mendirikan lembaga pendidikan mulai dari Play Group (KB), RA, TKIT, SDIT, SMPIT, sampai SMAIT, bahkan ada juga yang mendirikan ma'had perguruan tinggi. Tentu muatan kurikulum diorientasikan untuk menguatkan ideologi Islamism mereka. Kalangan Islamis juga mendirikan lembaga charity non profit yang menjadi sumber material pendanaannya. Hal terpenting penyebaran ideologi mereka dilakukan melalui media, baik massa maupun sosial, semua ditujukan untuk kepentingan ideologisasi.

Sejauh ini, melalui masjid gerakan Islamis telah merasuk ke semua lapisan masyarakat dan mengancam eksistensi kelompok Islam kultural tradisional seperti NU baik secara ideologis maupun ungkapan verbal melalui pengajian dan khutbah jumat yang mengandung unsur kebencian, fitnah dan provokasi. Secara doktrin, Islam tradisional mengedepankan Islam nusantara, kosmopolit, dan berdialog dengan budaya lokal. Sasaran kelompok Islamis adalah massa Islam tradisional agar jauh dari ideologinya serta majelis ta'limnya yang ada di masyarakat. Melalui majelis ta'lim dan khutbah jumat kelompok Islamis menjadikan media tersebut sebagai arena untuk menghakimi, menyebarkan kebencian, pengkafiran, penyesatan, pemurtadan, klaim bukan Islam, dan pelabelan negatif lainnya terhadap kelompok yang berbeda dengan mereka. Dengan dalih mengadakan pemurnian mereka kemudian "merebut" dan "menguasai" masjid kelompok Islam kultural-tradisional. Keberadaan mereka menjadi anti-tesis bagi Islam tradisional di Indonesia terutama Surakarta.

Surakarta menjadi kota penting dalam studi mengenai gerakan radikalisme keagamaan di Indonesia, bahkan kota ini menjadi laboratorium sosial keagamaan yang selalu menarik untuk diikiuti dinamikanya. Kota ini memiliki varian gerakan Islamis yang masif dibandingkan dengan kota lainnya di Indonesia. Ideologi Islamis tumbuh dengan subur, bahkan dengan leluasa mereka mengembangkan ideologinya dengan berbagai media. Meski jumlah mereka secara kuantitas tidak banyak, tetapi gerakan mereka cukup massif, dan "suara" mereka nyaring karena dikemas dengan framming yang bagus sehingga eksistensi gereka mereka tetap terjaga. Akibatnya, ideologi kekerasan, sektarian, dan intoleran kelompok Islamis ini menjadi virus puritan pada kelompok keagamaan yang lain di Surakarta.

Dewasa ini, masyarakat luas melihat masjid-masjid di kota Surakarta sebagai ruang publik untuk kontestasi perhelatan kelompok Islamis termasuk didalamnya melalui ujaran 
kebencian (hate speech) dengan program kegiatannya. Misalnya pembentukan DSKS (Dewan Syariah Kota Surakarta) dengan Ust Mu'inudinillah Basrai sebagai ketua, deklarasi ANNAS (Aliansi Nasional Anti Syiah) oleh Ust Tengku Azhar, KMM (Komunitas Masjidku Makmur) dengan tagline:" bersihkan masjidmu dari paham sesat," ketiga komunitas ini mempunyai fokus kajian pada bahaya Syi'ah dan komunisme (PKI) di tingkat nasional maupun lokal. Dengan wacana ini mendorong suburnya gerakan ujaran kebencian dan semakin mengukuhkan kota Surakarta sebagai basis gerakan Islamis. Realitas ini yang mendorong adanya relasi pergeseran konflik di Surakarta, dari konflik yang bersifat horisontal sosial bergser pada konflik online media massa dengan berbagai bentuk ujaran kebencian. Pertanyaan yang muncul adalah, mengapa Surakarta menjadi ladang tempat suburnya ujaran kebencian berbasis masjid? Apa faktor pendorongnya?. Mengapa masjid mempunyai peran yang signifikan dalam mempercepat penyebaran ujaran kebencian di Surakarta?. Fungsi masjid telah bergeser, dari media pendorong perubahan kehidupan dalam pengamalan beragama dan pembinaan umat, kini menjadi "media politik" untuk menyemai kebencian, menghakimi kafir, dan penyesatan yang akhirnya memunculkan ideologi kekerasan.

Ujaran kebencian dan sterotype yang marak di Surakarta, terutama berbasis masjid dan keagamaan dinilai tidak hanya mendorong tumbuh suburnya intoleransi, tetapi juga menyulut kelompok lain untuk melakukan kekerasan dan diskriminasi terjadap kelompok lain. Jjaran kebencian mempunyai peran baik langsung maupun tidak langsung atas terjadinya defisit dalam kebebasan beragama dan berkeyakinan. Hal ini terlihat dari meningkatnya berbagai kasus kriminalisasi terhadap ekspresi keagamaan yang dianggap "sesat" atau "menyimpang" serta kasus kekerasan terhadap kelompok minoritas. Kekerasan tersebut dapat dilakukan melalui berbagai media, baik itu khutbah jumat, ceramah, pamlet, spanduk, banner, poster, dan lainnya. Selain itu, ujaran kebencian mempunyai konstribusi terhadap berkembangnya terorisme berbasis radikalisme keagamaan. Hal ini terlihat dari berbagai kasus terorisme diadasarkan rasa tidak suka terhadap kelompok lain di luar dirinya.

Surakarta dan wilayah penyangga sekitarnya menjadi fenomena baru, sebab kota ini kini menjadi area perkotaan yang secara sosiologis ikatan sosial masyarakatnya menjadi longgar, individualis, dan kurang respon pada perubahan yang terjadi di lingkungan sekitarnya. Selain itu, Surakarta menjadi arus urbanisasi dan ruang bertemunya berbagai kepentingan, ideologi, ekonomi, dan budaya dari daerah penyangganya seperti Sukoharjo, Wonogiri, Klaten, Sragen, Boyolali, dan Karanganyar. Masyarakat Surakarta terlena dengan cepatnya perubahan sosial keagamaan yang ada. Akibatnya, tanpa sadar masyarakat kehilangan masjid sebagai basis ibadah spiritual karena adanya "politisasi agama" (tasyis ad-din) oleh kelompok Islamis. Masjid "seakan" berubah menjadi ruang publik yang sempit hanya untuk menghujat, memprovokasi, menghasut, memecah belah umat, dan menebar kebencian, radikalisme, bahkan kekerasan atas nama agama. Terlebih menjelang momentum demokrasi seperti Pilkada 2018 dan Pilpres 2019 maraknya gerakan "politisasi masjid" (tasyis al-masjid) menjadikan tempat ibadah ini sebagai ajang pencitraan pasangan calon tertentu meski dilakukan dengan cara menebar kebencian. Berangkat dari latar belakang di atas, maka artikel ini difokuskan untuk menjawab pertanyaan: pertama, apakah ada unsur-unsur ujaran kebencian pada khutbah di beberapa masjid yang ada di Kota Surakarta? Kedua, bagaimana implikasi atau pengaruh ujaran kebencian tersebut terhadap pola keberagamaan masyarakat Surakarta?

\section{METODE}

Penelitian terhadap dinamika ujaran kebencian melalui khutbah Jumat berbasis masjid dan implikasinya terhadap pola kehidupan keberagamaan masyarakat Kota Surakarta merupakan penelitian kualitatif deskriptif. Dengan penelitian kualitatif 
deskriptif diharapkan mampu mengungkap makna yang ada dari sisi pemikiran dan tindakan dari objek penelitian. Selanjutya agar penyampaian mengenai dinamika ujran kebencian berbasis masjid melalui khutbah jumat bisa lebih terbuka dan natural, maka dikemukakan dengan model deskriptif analitis. Penelitian ini menggunakan pendekatan sosiologi agama (Connolly, 2002: 267). Agama (Islam) ditempatkan sebagai fakta sosial (social fact), yakni sesuatu yang nyata dan dapat diamati serta mempengaruhi perilaku dan cara bertindak suatu masyarakat (Sodik, 2006: 78). Agama menjadi bagian dari kehidupan nyata pemeluknya yang terlihat dalam kehidupan keseharian pemeluk agama, gagasan, aktifitas, dan karya pemeluk agama (Kahmad, 2002: 62). Dengan kata lain, pendekatan sosiologi agama mempelajari aspek sosial agama (Suprayogo, dkk., 2003: 61).

Penelitian ini fokus pada tema/ materi khutbah jumat yang mengandung indikasi ada unsur ujaran kebencian dengan cara mengkomparasikan dari setiap masjid di Kota Surakarta sesuai klasternya. Pengumpulan data dalam penelitian ini dilakukan melalui tiga cara (Sutopo, 1998: 35). Pertama, observasi langsung, pengamatan secara langsung pada masjid-masjid di Kota Surakarta yang menjadi objek penelitian ini untuk mendapatkan materi/tema khutbah jumatnya. Kedua, wawancara mendalam pada khatib, takmir masjid/marbot, dan jamaah masjid yang bersangkutan mengenai content khutbah jumat yang disampaikan pada setiap masjid yang menjadi objek penelitian ini. Ketiga, mencatat dokumen, proses pencatatan diusahakan menuliskan berbagai hal secara cermat mengenai materi khutbah jumat dan prilaku keagamaan jamaah masjid yang bersangkutan. Sebelum analisa data dilakukan; pertama, peneliti mendiskripsikan hasil wawancara apa adanya; kedua, melakukan kategorisasi hasil temuan-temuan itu menurut jenis datanya yang disesuaikan dengan tujuan penelitian, sehingga data yang diperoleh menjadi terbuka dan terhindar dari melebarnya cakupan penelitian; dan ketiga, setelah dilakukan kategorisasi peneliti melakukan analisa secara kritis seluruh hasil temuan yang ada, sehingga data yang diperoleh dari kelompok milisia Islamis sudah memuat analisa yang tajam.

Teknik analisis data yang digunakan dalam penelitian ini adalah model analisis interaktif yang mencakup tiga tahap, yaitu: (1) reduksi data, proses menajamkan, mengarahkan, dan mengorganisasikan data. (2) Penyampaian data; (3) penarikan kesimpulan. Tahap reduksi data merupakan proses seleksi data mengenai materi/tema khutbah jumat yang mengandung unsur ujaran kebencian di masjid-masjid Kota Surakarta serta relgious epereinces-nya dalam kehidupan di tengah masyarakat. Dalam hal ini meliputi proses pemilihan, pemusatan perhatian pada penyederhanaan, pengabstrakan, dan tranformasi data kasar yang muncul dalam catatan tertulis di lapangan.

Pada tahap penyajian data dismapaikan hasil komparasi dari berbagai materi/tema khutbah jumat berbasis masjid di Kota Surakarta, peneliti menyajikan data dalam suatu susunan yang sistematis sesuai dengan alur yang telah dibuat. Pada penyajian data ini peneliti memungkinkan untuk menyajikan dalam bentuk gambar, matriks, dan skema. Hal itu dimaksudkan untuk memaparkan kondisi yang utuh dan terstruktur mengenai jaringan mengenai materi khutbah jumat yang mengandung unsur ujaran kebencian serta implkikasinya terhadap prilaku keagamaan masyarakat Surakarta. Untuk lebih menghargai perasaan informan peneliti menggunakan cara penyajian emik dan etik. Tahap penarikan kesimpulan berdasarkan analisis yang telah dilakukan. Tahap terakhir adalah penarikan kesimpulan. Kesimpulan yang didapatkan akan diuji kebenarannya dan validitasnya dengan dengan dua cara: (1) dengan triangulasi data; dan (2) review informan.

\section{HASIL DAN PEMBAHASAN}

\subsection{Setting Sosial, keterbukaan Politik, dan Dinamika Keagamaan Surakarta}

Pasca tumbangnya rezim Soeharto, Indonesia seperti rumah yang terbuka pintunya dengan lebar untuk semua ideologi, termasuk gerakan keagamaan anti mainstream yang 
mengusung pemurnian. Ruang publik selama Orde Baru berkuasa, ruang publik dikontrol dalam ruang keagamaan formal agar mudah dikendalikan negara. Di era reformasi, mulai menyebar pada pimpinan organisasi kemasyarakatan dan politik praktis. Ideologi tersebut berkembang bersamaan dengan gerakan Islam trans-nasional seperti Hizbut Tahrir (HT), Ikhwanul Muslimin (IM), Salafi, Syi'ah, dan lainnya. Kelompok ini berusaha menempatkan Islam dalam lingkar kekuasaan negara sebagai sistem yang mengatur aspek sosial, politik, ekonomi, budaya, dengan legitimisasi bahasa agama. Mereka menginiasi munculnya halaqoh, kajian, dan model hijrah yang kemudian bermetamorfosis membentuk simpulsimpul baru di masyarakat terutama di masjid-masjid sebagai basis gerakan mereka.

Keterbukaan pasca reformasi tersebut sebagai bentuk euforia identitas Islam berkembang secara masif di wilayah Surakarta dan sekitarnya. Hal ini menguatkan asusmsi bahwa Islam dijadikan kendaraan untuk mendapatkan simpati dari masyarakat luas sehingga mereka bisa mendominasi ruang publik di Soloraya. Sejauh ini, ruang publik menjadi area perebutan kekuasaan berbagai elemen sosial untuk mendesakkan agenda, isu, kepentingan, dan ideologi. Pola keberagamaan seperti ini yang mendorong muculnya gerakan Islam popular sehingga mengalami shifting paradigm epistemologi beragama dari trilogi tauhid, fikih, dan tasawuf, bergeser pada iman, jihad, dan hijrah.

Realitas di Surakarta, gejolak fanatisme dan gerakan keagamaan secara sosial sangat terasa karena dua hal: pertama, Kota Surakarta memiliki stigma sebagai kota yang melahirkan teroris. Hal ini bisa dirunut hampir setiap isu teroris mengemuka bisa dipastikan ada warga Soloraya yang menjadi aktor tersangkanya. Kedua, Kota Surakarta juga dikenal memiliki tingkat konflik sosial keagamaan yang tinggi sehingga berujung pada pelanggaran kebebasan beragama yang relatif tinggi. Fenomena gerakan keagamaan Islamisme juga telah merebak keberbagai kota lain seperti kota Surakarta. Sejak dahulu Surakarta terkenal sebagai pusat budaya Jawa, kota yang plural sekaligus kota yang banyak melahirkan para aktifis Islam radikal. Berbagai gerakan keagamaan sejak lama telah lahir dan berkembang di Kota Surakarta ini, misalnya Serikat Islam (1905) dan Sarekat Rakyat (1914) (Mulyadi, 1999: 235). Pada saat ini juga telah berkembang dengan pesat organisasi keagamaan seperti Nahdhatul Ulama (NU), Muhammadiyah, Majelis Tafsir Al-Quran (MTA), Majelis Mujahidin Indonesia (MMI), Jamaah Anshar Tauhid (JAT), Jamaah Anshar Syariah (JAS), LDII, Jamaah Al-Islam Gumuk, Jamaah Al-Madinah beragam front, menjamurnya berbagai laskar yang bercorak ideologis, dan berbagai majelis taklim, majlis dzikir, halaqoh,/pengajian, dan komunitas hijrah yang jumlahnya sangat banyak tumbuh subur di Surakarta (Aijudin, 2008: 37).

Ada sebagian kelompok keagamaan yang melakukan tindakan ujaran kebencian atas dasar keyakinan agama baik secara offline maupun online melalui media sosial seperti Fecbook (Fb), Instagram (IG), Twetter, dan lainnya. Dengan ujaran kebencian atas dalih "penistaan agama" dan "aksi bela agama" mereka memberikan label sesat, menyimpang, kafir, dan musyrik. Mereka disasar karena beda keyakinan, amalan, sikap beragama, dan pandangan, dan pemikiran keagamaannya. Persoalan tersebut hanya bisa diselesaikan dengan memperbesar ruang lingkup persaudaraan dan pertemanan, maka dengan sendiri kebencian, hasutan, dan provokasi pada akhirnya akan hilang dengan perlahan. Mereka yang menebarkan ujaran kebencian berbasis agama sudah tidak memperdulikan lagi nilainilai kemanusiaan dan kebersamaan dengan tujuan untuk memprovokasi konflik sosial. Alih-alih menggunakan agama sebagai media dakwah untuk kepentingan menebarkan kedamaian, justru mereka menggunakan agama disiarkan untuk kedengkian dan kemarahan pada kelompok yang berbeda. Jika hal ini tidak diantisipasi, maka ketegangan akan dengan mudah membara yang menyebabkan konflik sosial antar kelompok keagamaan dan etnis bisa sulit dicegah di Indonesia.

Maraknya khutbah-khutbah yang mengandung unsur ujaran kebencian sebelum ada media sosial di kota Surakarta secara prinsip memanfaatkan adanya keterbukaan kesempatan politik yang ada pasca reformasi 1998. Keterbukaan struktur politik pasca era 
reformasi telah mendorong kehadiran Islam di ruang publik sehingga mengalami perkembangan yang signifikan (Gaffar, 1999: 179). Ruang terbuka yang diberikan demokrasi telah menjembatani hadirnya kembali Islam politik (Islamisme). Sejak awal reformasi puluhan partai Islam berdiri, ormas keislaman juga tumbuh subur, dengan beragam orientasi ideologinya. Perkembangan gerakan keagamaan yang demikian pesat ini terlihat sebagai buah dari keterbukaan politik yang mendatangkan kesempatan dari beragam ideologi untuk berkembang (Jamil, 2007: 95). Di sisi lain, munculnya beragam gerakan sosial keagamaan tersebut merupakan bukti adanya polarisasi ideologi gerakan sosial keagamaan yang ada di Indonesia.

Menurut teori gerakan sosial perspektif Political Opportunity Structure (POS) disebutkan ketika ada peluang politik yang terbuka, akan ada gerakan sosial yang memanfaatkan kondisi tersebut termasuk mimbar khutbah di masjid-masjid di Surakarta seperti yang menjadi fokus pada penelitian ini. Karena itu, gerakan sosial dalam bentuk khutbah Jumat di masjid-masjid Surakarta terjadi karena adanya perubahan dalam struktur politik yang dilihat sebagai kesempatan. POS selalu berhubungan dengan sumber daya (resources) yang bersifat eksternal. Sumber daya ini dipergunakan oleh pelaku perubahan melalui terbukanya akses politik dan jejaring kepada kelembagaan politik dan perpecahan di tubuh elit politik untuk melakukan perubahan (Tarrow, 1998: 20). Gerakan sosial seperti khutbah-khutbah Jumat di masjid-masjid Surakarta muncul ketika tingkat akses terhadap lemabaga-lembaga formal mengalami keterbukaan, ketika keseimbangan politik tercerai-berai dan kekuatan politik baru belum terbentuk dan ketika elit politik mengalami konflik besar dan konflik ini dipergunakan oleh para pelaku perubahan sebagai kesempatan (Singh, 2001: 102).

Dinamika perkembangan gerakan sosial, politik, dan keagamaan di kota Surakarta menjadi marak dan meriah. Hal ini menjadikan kota ini sebagai basis gerakan keagamaan dengan beragam ideologi, dari kanan sampai kiri. Secara prinsip, gerakan keagamaan anti mainstream di Kota Surakarta yang aktornya banyak digawangi oleh pondok pesentren, lembaga pendidikan, lembaga chariti, dan komunitas-komunitas kecil yang disebagai laskar. Salah satu gerakan anti mainstream di lokal merupakan salah satu gerakan keagamaan yang berbasis pada masjid-masjid dengan model halaqoh yang memfokuskan pada kajian keislaman bernuansa ideologis, seputar TBC (takhayul, bid'ah, dan khurafat), penegakkan syariat Islam, dan khilafah Islamiyah.

Gerakan politik keagamaan mereka menjadikan masjid sebagai basis ideologisasi melalui khutbah Jumat dengan mengembangkan wacana purifikatif dengan orientasi formalisasi syariat Islam di Indonesia. Bermula dari khutbah Jumat di masjid-masjid ini kemudian memunculkan gerakan sosial untuk penegakkan syariat bahkan khilafah Islamiyah yang hadir dan memberikan warna politik keagamaan di ruang publik Surakarta (Fauzi, dkk.: 2009). Selain itu, khutbah-khutbah Jumat yang ada di beberapa masjid di Surakarta rata-rata seragam sejalan dengan karakter ideologis gerakan mereka. Hal ini terlihat dari akses jaringan dari pengisi khutbah tersebut, hampir semua khatibnya dari kalangan in-group mereka.

Berangkat dari khutbah Jumat kemudian menjadi gerakan sosial di Surakarta, gerakan Islamisme menempatkan Islam sebagai bagian dari aksi politik mereka yang bersandar pada paradigma Islam sebagai agama yang sempurna telah menyediakan segala aturan bernegara dan bermasyarakat. Faktor penting yang mendasari pandangan ini adalah Islam merupakan solusi bagi masyarakat Indonesia yang mayoritas muslim dan hukum yang ada saat ini tidak memberi rasa keadilan (Effendi, 2010: 405). Paradigma ini yang menyatakan Islam sebagai agama yang sempurna dengan Din (agama), Dawlah (negara), dan Dunya (dunia) ini menjadikan parameter gerakan sosial mereka yang bersifat tekstual dan purifikatif sehingga dalam praktiknya di lapangan lebih mengedepankan pola intoleran dan kekerasan atas nama agama. 
Khutbah Jumat merupakan media penting dalam membangun kesadaran keberagamaan masyarakat, sebegaimana Tarrow menyebut hal ini sebagai sesuatu yang memunculkan gerakan sosial, secara prinsip didorong tiga hal, sumber daya, motivasi, dan lingkungan politik (Mibtadin, 2017: 59). Dalam gerakan sosial sumber daya tersebut dapat berupa material, media massa, legitimasi, otoritas, identitas, dan institusional (Tarrow, 1998: 15). Khutbah Jumat menjadi sumber daya material yang dimiliki umat Islam, baik mereka yang mengusung wacana Islam maintsream maupun kalangan Islamis antara lain jamaah dengan segala potensinya baik ekonomi, sosial, budaya, keagamaan dan politik. Selain itu, narasi khutbah Jumat menjadi sumber daya material tersendiri sekaligus media framing dalam mengkampanyekan wacana keislaman moderat. Dengan khutbah Jumat tersebut menjadi simpul yang mampu menggerakan kekuatan jamaahnya untuk melakukan perlawanan kultural terhadap kelompok mainstream.

Lewat khatib dan kontennya khutbahnya menjadi otoritasnya yang mampu menggerakkan masyarakat sebagai media framing untuk mendorong tumbuh berkembangnya kesadaran keberagamaan jamaahnya. Keberadaan khatib menjadi agen dan masjid sebagai struktur untuk menggerakan perubahan di masyarakat Surakarta dengan penguatan pada basis sosial keagamaan. Hanya kalangan in-group mereka yang bisa berkomunikasi, memahami bahasa masyarakat bawah untuk menyampaikan pesan pentingnya pola keberagamaan moderat. Hasil penelitian tidak menemukan adanya khatib yang menyampaikan narasi khutbah provokatif sehingga mendorong the seed of Islamism Muslims dan perlawanan terhadap budaya lokal yakni kultur sipil. Secara prinsip, kultur sipil adalah nilai, norma, serta moral guide di masyarakat yang menghormati aspek pokok dalam wacana demokrasi seperti kemanusiaan, toleransi, kesetaraan, pluralisme, HAM, penghargaan pada minoritas dan kemandirian.

Nilai keislaman moderat yang disampaikan khatib melalui khutbah Jumat tersebut pada akhirnya mendorong Islam sebagai agama yang bermain pada ranah civil society yakni menjadi moral reasoning bagi pengembangan masyarakat. Karena itu, agama tidak penah menjadi dominan melalui kelompok keagamaan tunggal, termasuk memberi legitimasi kepada gerakan-gerakan politik sebagai satu-satunya kebenaran. Islam adalah agama diyakini relevan dengan zaman (as-sholih likuli zaman wa al-makan), ia tidak boleh kehilangan transendensi dan harus menyejarh dalam kontek kehidupan masyarakat. Semakin ia identik dengan pengaturan kelembagaan tertentu, agama dianggap makin kehilangan nilai-nilai transendensinya.

Selain itu, beragam khutbah dengan materi dan konten yang berbeda dipahami sebagai bentuk perlawanan (contentious) sekaligus kritik sosial terhadap kelompok Islam tradisional yang mengusung ideologi Ahl as-Sunnah wal-Jama'ah. Terhitung sejak reformasi 1998, di Surakarta banyak bermunculan gerakan Islam ideologis yang menawarkan pendekatan kekerasan untuk melawan wacana mainstream yang satunya muncul karena dorongan untuk tetap eksis. Menurut Hefner, kehadiran gerakan Islam militan ideologis di ruang publik tidak secara langsung dianggap sebagai ancaman bagi demokrasi itu sendiri. Sebab, keberadaan Islam di ruang publik Indonesia tidak bersifat monolitik, tetapi plural, seperti politik pada semua peradaban (Hefner, 2000:). Sebaliknya, kemuculan kelompok Islamis dipahami sebagai bentuk perlawanan terhadap gerakan keagamaan dominan seperti NU yang mengusung wacana mainstream. Akibatnya, muncul ketegangan (tension) antara gerakan Islamis dengan masyarakat luas yang memiliki otoritas dan ortodoksi. Gerakan ini ingin menunjukkan eksistensi dirinya secara frontal kepada masyarakat yang menganggap keberadaan mereka termarginalkan. Dengan truth claim, mereka berkeyakinan, kelompoknya yang paling benar, paling otoritatif dalam memberikan tafsiran agama. Meski dukungan masyarakat kepada mereka tergolong rendah namun kehadiran organisasi radikal bisa menjadi salah satu faktor yang meradikalisasi masyarakat menjadi intoleran. 
Kehadiran Islam di ruang publik seperti yang ditampilkan oleh khatib pada khutbah Jumat di beberapa masjid di Surakarta dipahami sebagai simbol, identitas, dan nilai Islam pada masyarakat dengan memanfaatkan ruang terbuka. Baik nyata maupun virtual yang digunakan secara bersama oleh jamaah untuk mengkomunikasikan gagasan dan kepentingan, termasuk kepentingan politik dan agama. Karena itu, terbukanya ruang kontestasi masa reformasi biasanya kurang diapresiasi oleh kelompok gerakan sosial Islam mainstream dengan mengkonsolidasi diri menata strategi mereka. Sebaliknya, keterbukaan tersebut dimanfaatkan dengan baik oleh gerakan sosial kelompok Islam ideologis untuk show force dengan mendesakkan agenda-agenda Islamis di tengah pluralitas kehidupan masyarakat Surakarta. Sehingga rasa kebangsaan dan keberagamaan moderat mulai bergeser bahkan terpinggirkan dengan menguatnya radikalisme agama.

\subsection{Khutbah, Jamaah, dan Konstruksi Realitas Keagamaan di Ruang Publik}

Khutbah secara terminologi adalah perkataan yang disampaikan khatib di atas mimbar, atau perkataan yang mengandung nasehat dan informasi keagamaan sesaat sebelum melaksanakan shalat Jumat yang disertai dengan niat dan dilafalkan dengan ucapan yang keras. Secara prinsip fungsi khutbah Jumat adalah sebagai cara pandang dan berpengaruh terhadap kehidupan beragama jamaah di masjid di Surakarta seperti Sampangan, Baitul Hikmah, Al-Manar, Al-Wustha, Agung, Jami' MUI, Ummu Umar, Sholihin, PKU Muhammadiyah dan lainnya. Khutbah Jumat yang disampaikan akan membentuk logical frame work jamaah sehingga bisa memahami Islam secara utuh, kaffah, dan totalitas Islam sebagai agama rahmatan lil'alamin. Dengan pemahaman keagamaan tersebut sangat kecil kemungkinan memunculkan kekerasan dengan corak teologis menjadikan agama tidak bebas dari kepentingan manusia. Adanya khutbah yang sejuk, toleran, dan moderat bisa menghindarkan dari sikap dan paham keagamaan yang fundamental, bahkan mengorbankan manusia dengan mengatasnamakan Tuhan. Beberapa khatib di masjid-masjid di Surakarta yang menjadi locus penelitian secara umum menyampaikan khutbah yang bersifat mendidik dan jauh dari unsur ujaran kebencian dan menistakan prinsip kemanusiaan. Selain itu, khatib juga menempatkan Islam sebagai agama cinta, ajaran kasih dan pembawa misi perdamaian, dan bukan ajaran agama yang berifat "evil" jahat yang mengarah pada dehumanisasi, mendorong hate speech, dan melukai nilai-nilai kemanusiaan.

Khatib yang menyampaikan khutbahnya di beberapa masjid di Surakarta secara prinsip meneguhkan eksistensi Islam yang akhir-akhir ini mulai dipertanyakan di ruang publik oleh sebagian kalangan, apakah kehadiran agama untuk memisahkan manusia dengan "sekat ideologis" atas nama agama atau kehadiran agama untuk memperteguh nilai-nilai kemanusian universal?. Meskipun demikian, sejak awal kehadirannya bahwa Islam merupakan agama yang pembawa pesan esensial untuk kemanusiaan dan perdamaian, tetapi realitas menunjukkan justru sebaliknya. Umat beragama malah tidak malu, bahkan lebih suka mempermalukan diri dan Tuhan-nya dengan berkonflik atas nama perbedaan madzab, ideologi, dan pembelaan terhadap doktrin kepercayaannya. Mereka lebh suka menggunakan kekerasan dan menebar ujaran kebencian (hate speech), hoax, dan fitnah kepada pemeluk agama lain yang bisa menjadikan ketidakharmonisan dalam hubungan beragama. Hal ini yang menjadikan Islam kehilangan sentuhan kemanusiaan, toleransi, dan penghargaan terhadap yang beda. Karena itu, Islam masa depan adalah "agama baru" yang menekankan sikap toleransi (tasamuh) dan kerjasama untuk mewujdukan kemanusiaan universal.

Berkaitan dengan "agama baru" yang menekankan sikap tasamuh, tawazun, dan ta'adul, beberapa khutbah jumat yang ada di masjid Surakarta mengembangkan tematema yang mendukung wacana tersebut. Secara umum, tema-tema tentang normativitas doktrin Islam dikaitkan dengan realitas kehidupan umat sangat dominan. 
Tabel 1. Tema khutbah berdasarkan masjid

\begin{tabular}{|c|c|c|}
\hline No & Nama Masjid & Tema Khutbah \\
\hline \multirow[t]{2}{*}{1.} & \multirow{2}{*}{$\begin{array}{l}\text { Majid Balai Kota } \\
\text { Baitul Hikmah }\end{array}$} & Pentingnya Alquran dalam Kehidupan Manusia \\
\hline & & Kemulian Ajaran Islam \\
\hline \multirow[t]{2}{*}{2.} & \multirow[t]{2}{*}{ Masjid Al-Manar } & Mencintai Alquran \\
\hline & & Puasa dan Kesalehan Sosial \\
\hline \multirow[t]{2}{*}{3.} & \multirow{2}{*}{$\begin{array}{l}\text { Masjid Al-Wustha } \\
\text { Mangkunegaran }\end{array}$} & Ramadhan sebagai Bulan Tarbiyah \\
\hline & & Keutamaan Malam Lailatul Qodr \\
\hline \multirow[t]{2}{*}{4.} & \multirow{2}{*}{ Nur Jamil Nusukan } & Istiqomah dalam Beribadah \\
\hline & & Menyambut Bulan Syawal \\
\hline \multirow[t]{2}{*}{5.} & \multirow[t]{2}{*}{ Masjid Sampangan } & $\begin{array}{l}\text { Pendidikan Keimanan dan Ketaqwaan dari Kisah Nabi } \\
\text { Ibrahim dan Ismail }\end{array}$ \\
\hline & & Hikmah berkurban \\
\hline \multirow[t]{2}{*}{6.} & \multirow{2}{*}{$\begin{array}{l}\text { Masjid Sholikhin } \\
\text { Punggawan }\end{array}$} & Keutamaan Bulan Ramadhan \\
\hline & & Nilai-nilai Utama Puasa \\
\hline \multirow[t]{2}{*}{7.} & \multirow[t]{2}{*}{ Masjid Agung } & Ramadahan dan Kepedulian kepada Sesama \\
\hline & & Menyambut Bulan Kemengan \\
\hline \multirow[t]{2}{*}{8.} & \multirow{2}{*}{$\begin{array}{l}\text { Masjid PKU } \\
\text { Muhammadiyah }\end{array}$} & Kewajiban Mengeluarkan Zakat \\
\hline & & Keberkahan Bulan Ramadhan \\
\hline \multirow[t]{2}{*}{9.} & \multirow{2}{*}{$\begin{array}{l}\text { Masjid Ummu Umar } \\
\text { Nusukan }\end{array}$} & Tingkatan Puasa Kaum Muslimin \\
\hline & & Puasa dan Kritik Sosial \\
\hline \multirow[t]{2}{*}{10.} & \multirow[t]{2}{*}{ Masjid Jami' MUI } & Hikmah Halal Bihalal \\
\hline & & Keutamaan Menyambung Silahturahim \\
\hline
\end{tabular}

Melihat tema khutbah di masjid di Surakarta semua terkait dengan prinsip-prinsip dasar dalam beragama, hal ini sejalan dengan pandangan Haedari bahwa pandangan dasar beragama tersebut mendorong sikap inklusif, terbuka, dan menjauhi sikap keberagamaan yang radikal karena bisa mendorong krisis kemanusiaan berupa konflik sosial atas nama kepentingan agama (Haedari, 2006: 72). Khutbah menjadi media untuk mengkonstruksi realitas keagamaan di ruang publik yang secara umum menampilkan wacana keagamaan humanis dan toleran sehingga bisa meminalisir krisis keagamaan akibat adanya kesenjangan yang cukup dalam antara aspek normativitas dan historisitas dari agama itu sendiri (Abdullah, 2005: xx). Artinya, krisis keagamaan ini muncul disebabkan adanya klaim kebenaran atas tafsir keagamaan yang sepihak serta kuatnya sikap eksklusivisme dalam beragama. Dari tema-tema khutbah di atas, tidak ada temuan yang mengarahkan jamaah untuk bersikap eksklusif dan menutup diri dari the others. Sebab sikap eksklusif ini berdasarkan pada anggapan bahwa pemahaman keagamaan mereka, baik kelompok maupun individu memiliki pemahaman yang paling benar. Sehingga orang di luar kelompok mereka adalah salah serta "harus diselamatkan" dengan jalan mengikuti apa yang mereka pahami tentang doktrin ajaran agama tersebut. Dalam gerakannya, kelompok ini seringkali melakukan dengan jalan radikal atau tindak kekerasan yang mengatasnamakan Tuhan (Kurtz, 1995: 215). Sikap ini juga sering diikuti sikap anti dialogis yang menolak menggunakan cara beradab untuk menemukan solusi bersama.

Masjid sebagai ruang publik menjadi media untuk pembentukan wacana, cara pandang, dan penguatan narasi keagamaan moderat, salah satunya melalu khutbah jumat yang pada akhirnya bisa menggerakan nalar keberagamaan jamaah pada kehidupan sosial yang sesungguhnya. Melalui tema-tema keislaman moderat yang disampaikan khatib di masjid-masjid di Surakarta bisa menekan beberapa cara pandang kelompok keagamaan Islamis yang dewasa ini berkembang luas di kota yang memiliki slogan: the Spirit of Java tersebut. Pertama, mereka berprinsip mengembalikan semua pada Alquran dan hadits; 
kedua, dari kondisi tersebut yang muncul kemudian adalah klaim kebenaran. Karena meresa telah sesuai dengan Alquran dan sunnah maka mengagnggap bahwa para pelaku bid'ah adalah orang yang "salah" dalam beragama. Mereka harus dikembalikan ke jalan yang benar sesuai dengan makna literal dalam Alquran dan sunnah. Islam yang bersinergi dengan tradisi dianggap sebagai praktik yang tidak murni dan memiliki potensi syirik maka harus dikikis sampai tuntas.

Ketiga, pemahaman seperti itu menuntun orang hanya memahami agama dalam satu versi saja tidak memiliki pemahaman yang beragam. Akibatnya komunitas yang dimiliki orang lain yang berijtihad menjadi terabaikan. Dalam tema khutbah di atas, secara prinsip membangun keseimbangan antara narasi keagamaan bayani, burhani, dan irfani, yaitu bagaimana Islam dilihat selain sebagai doktrin yang bersifat mutlak universal juga sebagai logical framework yang mempunyai kepedulian terhadap nilai-nilai kemanusiaan seperti yang tercermin dalam tema khutbah: puasa dan kritik sosial. Mereka tidak menyadari bahwa apa yang mereka sampaikan yang dianggap sebagai tafsir paling benar adalah sekedar salah satu ijtihad saja dalam memahami Alquran dan hadist. Masih banyak kelompok lain yang juga memiliki ijtihad yang bisa dijadikan media dan acuan untuk memahami sumber dasar ajaran islam. Disinilah kemudian muncul klaim kebenaran, yang menjadikan dikursus antara aku dan kamu, al-ana dan al-akhor, i'am dan the others. Keempat, pola praktik beragama tersebut akan menjadikan sesorang megalami kekeringan dalam beragama dan akhirnya split personality. Orang terpaku pada teks saja sedangkan konteks menjadi sangat minim bahkan sering dikesampingkan. Disinilah pentingnya keberadaan khatib dengan narasi teks keagamaannya memberikan perspektif bagi jamaah sehingga terbangun kesadaran cara beragama yang moderat, toleran, dan mengedepankan penghormatan pada yang lain.

Pewacanaan narasi keagamaan melalui khutbah Jumat adalah upaya menampilkan Islam di ruang publik untuk bertarung memperebutkan ruang agar bisa mendominiasi diskursus di pusat gerakan. Ruang publik adalah wilayah dimana semua warga masyarakat dapat dengan leluasa melakukan aktivitas sosial, politik, dan ekonominya tanpa ada dominasi oleh individu atau komunitas lainnya (Gaffar, 1999: 79). Dalam artikel ini, ruang publik yang dimaksudkan adalah masjid yang semua komunitas umat Islam bisa mengakses dan melakukan kegiatan secara leluasa, termasuk dalam menyampaikan halaqoh, kajian, pengajian, maupun khutbah jumat. Menurut Habermas, ruang publik dipahami sebagai dunia kehidupan sosial dimana sesuatu yang berkaitan dengan opini publik dibentuk (Habermas, 1991: 2). Ruang sosial ini mensyaratkan keterpisahan dari struktur formal yang didalamnya terdapat otoritas politik dengan struktur privat seperti rumah tangga, komunitas, dan institusi agama. Wilayah ini kemudian berkembang menjadi ranah kontestasi penguatan ideologi dan diperebutkan oleh semua elemen sosial yang berkepentingan untuk memperkuat dominasinya (Habermas, 2012: 167).

Sedangkan dalam teori gerakan sosial, materi khutbah jumat dipahami sebagai bentuk framing yakni upaya strategis secara sadar oleh kelompok atau individu untuk membentuk pemahaman bersama tentang dunia dan diri mereka sendiri, yang mengabsahkan dan mendorong terjadinya aksi kolektif. Salah satu bentuk framing adalah pengemasan wacana dan materi khutbah yang menjadi social capital dalam mempengaruhi jamaah yang hadir di masjdi-masjid di Surakarta untuk bersikap dan berperilaku beragama di tengah masyarakat. Khutbah sebagai media framing terkait dengan tujuan perebutan makna di masyarakat. Jamaah dalam mengikuti khutbah itu sendiri memang didorong oleh motif untuk memperoleh capitals, walaupun dalam konteks internal agama sendiri (Ikhwan, dkk., 2013: 150). Wacana agama bukan dijadikan sebagai wacana pembebas dan pengejawantahan harmonisasi hubungan antar agama yang bersifat humanis dan antroposentris. Tetapi, teks-teks keagamaan termasuk narasi khutbah Jumat ditafsirkan sebagai bagian dari teosentris dan bersifat skriptual-literalis yang hampa dari ruang dan waktu, sehingga ketika wacana agama dibumikan secara 
praksis berubah wajahnya menjadi sesuatu yang eksklusif, dogmatis, dan mudah menyalahkah orang lain di luar dirinya.

Wacana di atas menjadikan pola berislam yang ada sudah tidak sehat karena telah kehilangan ruh kemanusiaan (ar-ruh al-insaniyah). Melalui tema-tema khutbah Jumat, khatib selalu mengarahkan dan mengembalikan Islam pada jalurnya yakni sebagai pedoman yang membawa pesan perdamaian dan keharmonisan sosial di tengah masyarakat plural seperti di Surakarta. Khatib menyampaikan, misi Islam adalah kemanusiaan seperti yang terlihat pada tema puasa dan kesalehan sosial, serta tema pentingnya Alquran dalam kehidupan manusia. Wacana tersebut menjadi counter narasi terhadap klaim kelompok Islamisme, agama menjadi sesuatu dengan mengedepankan teologi kekerasan sebagai sacred violence yang muncul dari teks-teks suci dan tafsir agama, juga disebabkan karena agama dijadikan pandangan yang serba magis dan serta mutlak ketuhanan. Agama Islam hanya berdimensi teosentris, dan bukan antroposentris, sehingga tidak bisa diinterpretasikan bahkan ditundukkan di bawah keinginan manusia. Dengan demikian, agama telah menjadi "berhala baru" karena orang beragama menempatkannya sebagai idolatry bukan sebagai kritik sosial dan proses antropologis. Sikap dan cara beragama seperti inilah yang menjadikan mereka merasa sikap beragamanya paling benar, sempurna, dan mutlak, sehingga orang lain dianggap salah dan harus dipertobatkan (Qodir, 2003: 168).

Menurut Imam Baehaqi menyatakan, Islam dan kemanusiaan adalah pertarungan antara doktrin dan historisitas, karena membicarakan kembali doktrin dan realitas sejarah tidak lain adalah untuk mengembalikan wacana doktrin pada konteks sejarahnya. Maka diperlukan penafsiran-penafsiran ulang demi menggali kembali prinsip-prinsip dasar yang ideal dari agama untuk menjawab berbagai tantangan kemanusiaan dan kemasyarakatan (Baehaqi, Bernas: 1996). Penafsiran baru dengan metode, pendekatan, maupun nalar filosofis ini sangat diperlukan, jika dikaitkan dengan kenyataan agama yang tidak jarang justru malah disalahgunakan umatnya untuk meligitimasi penindasan dan kekerasan yang mengatasnamakan Tuhan. Kritik sosial melalui khutbah tang disampaikan oleh khatib pada masjid-masjid di Surakarta pada dasarnya menekakan arti penting nilai-nilai kemanusiaan sebagai bentuk dekonstruksi terhadap cara berpikir dan beragama yang tekstual-normatif. Sebagai agama, Islam secara esensial mengandung prinsip-prinsip dasar (maqashid al-syaria'ah) yakni misi universal syariat Islam yang diarahkan untuk kesejahteraan manusia.

Hampir semua tema khutbah yang ditemukan selama penelitian ini tidak ada yang mengharakan pada pola keberagamaan yang puritan dan menuju gerakan pemurnian dengan kredo kembali kepada Alquran dan sunnah. Meski ada tema tentang mencintai Alquran dan pentingnya dalam kehidupan manusa, secara prinsip tidak menekankan untuk menjadi puritan pada jamaahnya. Karena itu, sebenarnya kredo ini bukanlah hal yang asing bagi umat Islam, sebab semua umat Islam mendasarkan pemikirannya dan perilakukanya berdasarkan penafsiran mereka tentang Alquran dan sunnah. Meskipun demikian, dalam pemikiran Islam murni hal tersebut bukan sesuatu yang perlu dipertimbangkan, sebab dalam versi pemurnianlah kredo kepada Alquran dan sunnah itu diyakini memiliki otentisitas. Kredo ini dalam versi pemurnian dipahami sebagai upaya dan keinginan secara sungguh-sungguh mengikuti cara-cara Rasulullah Saw yang benar dalam menjaga ajaran Islam.

Bagi khatib dalam menyampaikan khutbah Jumat dengan tema Alquran mengarahkan pada cara beragama yang benar adalah menggunakannya sebagai dasar utama dalam kehidupan. Hal ini kemudian menjadi nilai ideologis yakni cara pandang (worldview) yang dikembangkan oleh jamaah setelah selesai khutbah Jumat di tengah kehidupan masyarakat. Dengan khutbah tersebut pengakajian terhadap Alquran meningkatkan pemahaman, penghayatan, dan pengamalannya kedalam kehidupan keseharian. Khatib 
berharap melalui khutbah tersebut jamaah bisa dengan berpegang teguh pada Alquran, dan masyarakat bisa terhindar dari semua kesalahan dalam beragama.

Praktik beragama yang humanis, toleran, dan menghargai perbedaan dalam khutbah di masjid-masjid Surakarta selalu diwacanakan terutama pada awal khatib memulai khutbah. Dengan pemahaman keagamaan yang benar dan terbuka diharapkan jamaah dapat menjalankan ajaran agama dengan benar sesuai dengan nilai-nilai Alqurani, menghindari perbuatan yang mengandung nilai kekerasan tidak menebar ujaran kebencian. Materi mencintai Alquran dan pentingnya dalam kehidupan manusia" adalah dalam upaya menyatukan pemahaman dalam memahami agam Islam secara holistik, komprehensif, dan multi perspective karena berimpilkasi dalam konteks masyarakat multikultur seperti di Surakarta. Secara sosiologis berdampak pada sikap keberagamaan yang tidak mudah menyalahkan dan menghakimi orang lain, menebar fitnah, haoax, dan bentuk ujaran kebencian lainnya.

Secara tematik, dalam materi khutbah yang disampaikan khatib di masjid Surakarta tidak bermuatan provokatif yang mengarahkan pada stereotype dan ujaran kebencian. Meski di Surakarta akhir-akhir ini marak memgenai hal tersebut, tetapi tema itu tidak pernah diangkat di atas mimbar khutbah jumat. Hal ini dikarenakan stereotype, fitnah, ujaran kebencian akan sangat berbahaya jika disampaikan dengan muatan narasi keagamaan terlebih di dalam ruang publik seperti masjid melalui khutbah, kajian, ceramah, pengajian, maupun halaqoh. Kedewasaan beragama yang ditampilkan khatib dengan mewacanakan beragama secara moderat ini berperan penting dalam terciptanya keutuhan dan kerukunan intra dan antar umat beragama di Surakarta. Melalui khutbah Jumat tersebut akan berpengaruh terhadap pola pikir dan prilaku keagamaan yang tidak membeda-bedakan kelompok keagamaan berdasarkan afiliasi ormas, politik identitas, dan keterikatan pada organisasi tertentu, mereka semua didorong untuk bisa aktif dalam partisipasi publik, bersama membangun kebersamaan, kerukunan, dan toleransi. Khutbah yang ada secara prinsip menyemai benih-benih toleransi, pluralisme, dan menghargai yang lain dalam keragaman sehingga tidak ada kelompok keagamaan yang merasa dipinggirkan dan disalahkan.

\section{KESIMPULAN}

Khutbah jumat berfungsi baik secara individual maupun sosial dalam penguatan narasi keagamaan umat Islam yaitu memberikan pengajaran (tarbiyah) kepada jamaah, mendorong jamaah untuk meningkatkan keimanan kepada Allah Swt., mengajak jamaah untuk mewacanakan Islam ramah di tengah masyarakat yang mengedepankan prinsip 'amar ma'ruf nahi munkar, dan menyampaikan informasi mengenai perkembangan ilmu pengetahuan, wacana keagamaan, dan trend issues yang sedang up to date. Khutbah jumat menjadi cara pandang dan berpengaruh terhadap kehidupan beragama jamaah di masjid Surakarta seperti Sampangan, Baitul Hikmah, Al-Manar, Al-Wustha, Agung, Jami' MUI, Ummu Umar, Sholihin, PKU Muhammadiyah dan Nur Jamil.. Khutbah Jumat uyang disampaikan akan membentuk logical frame work jamaah sehingga mereka bisa memahami Islam secara utuh, kaffah, dan totalitas sebagai agama rahmatan lil'alamin. Adanya khutbah yang sejuk, toleran, dan moderat bisa menghindarkan dari sikap dan paham keagamaan yang fundamnetal. Beberapa khutbah di masjid-masjid di Surakarta yang menjadi locus penelitian secara umum menyampaikan khutbah yang bersifat mendidik dan jauh dari unsur ujaran kebencian dan menistakan prinsip kemanusiaan. Terkait dengan implikasi khutbah, paling tidak secara wacana banyak memberikan pengaruh terhadap pola prilaku jamaah yang menjadi pendengarnya sehingga bisa bersikap toleran dan menghargai kepada kelompok di luar dirinya. 


\section{DAFTAR PUSTAKA}

Abdullah, M. Amin, 2005. "Kesadaran Multikultural sebagai Gerakan Interest Minimalization dalam Meredakan Konflik Sosial, "dalam Kata Pengantar, Pendidikan Multikultural: Cross Cultural Understanding untuk Demokrasi dan Keadilan. Yogyakarta: Pilar Media.

Aijuddin, Anas, 2008. Laporan Penelitian Transformasi Sosial Gerakan Keagamaan di Surakarta. Jakarta: Puslitbang Kemenag RI.

Baehaqi, Imam, "Wacana Islam dan Kemanusiaan" Bernas, Desember 1996.

Connolly, Peter. 2002. Approaches to the Study Religion, terj. Imam Khoiri. Yogyakarta: LKiS.

Effendi, Effendi, 2010. Islam dan Negara. Jakarta: Paramadina.

Engineer, Asghar Ali. 2002. Islam dan Teologi Pembebasan, terj. Agung Prihantoro. Yogyakarta: LKiS.

Faishol, Abdullah, dkk., 2007. Metode dan Teknik Kuliah Kerja Transformatif; Implementasi Participatory Action Research (PAR) dan Participatory Rural Appraisal (PRA) Untuk Aksi Perubahan Sosial. Surakarta: P3M STAIN Surakarta.

Fanani, Zainuddin, 2002. Radikalisme Keagamaan dan Perubahan Sosial. Surakarta: UMS Press dan ASIA Foundation.

Fauzi, Ali Ikhsan dan Saiful Mujani, 2009. Gerakan Kebebasan Sipil. Studi dan Advokasi Atas Perda Syariah. Jakarta: Nalar.

Gaffar, Afan, 2004. Politik Indonesia. Transisi Menuju Demokrasi. Yogyakarta: Pustaka Pelajar.

Habermas, Jurgen, 1991. The Structural Transformation of the Public Sphere, trans. Thomas Burger, Cambridge: The M. IT Press.

Habermas, Jurgen, 2012. Ruang Publik. Sebuah Kajian Tentang Masyarakat Bourjuis, terj. Yudi Santoso. Bantul: Kreasi Wacana.

Haedari, M., 2006. "Agama dan Tantangan Kemanusiaan Kontemporer," dalam Jurnal AlQolam Vol 23, No 2 Agustus 2006.

Ichwan, Moch Nur, dan Ahmad Muttaqin (ed.), 2013. Islam, Agama-agama, dan Nilai-nilai Kemanusiaan: Festschrift untuk M. Amin Abdullah. Yogyakarta: CISForm.

Idahram, Syaikh, 2011. Mereka Memalsukan Kitab-kitab karya Ulama Klasik: Episode Kebohongan Publik Sekte Salafi Wahabi. Yogyakarta: Pustaka Pesantren.

Jami, Mukhsin, 2007. Agama-agama Baru di Indonesia. Yogyakarta: Pustaka Pelajar.

Kahmad, Dadang S., Sosiologi Agama. Bandung: Rosda Karya

Kurtz, Lester, 1995. Gods in the Global Village. London: the Words Religions in Sociological Perspective.

Mibtadin, 2017. Gerakan Sosial Masyarakat Sipil. Studi Gerakan Sosial LKiS, Fahmina, dan The Wahid Institute. Yogyakarta, UIN Suka, Disertasi tidak diterbitkan.

Mulyadi, Hari, dkk., 1999. Runtuhnya Kekuasaan Keraton Alit. Studi Mobilisasi Sosial Masyarakat Solo dan Kerusuhan Mei 1998 di Surakarta. Surakarta: LPTP.

Qodir, Zuly, 2003. "Kekerasan dan Problem Dialog" dalam Jurnal Millah, Vol. II, No. 2, Januari 2003.

Salvatore, Armando and Dale F Eickelman, 2004, "Publices Muslim", in Public Islam and the Common Good, ed, Armando Salvatore and Dale F Eickelman, Leiden: BRILL.

Singh, Rajendra, 2001. Social Movement, Old And News; A Post Modernist Critique. London EC2A 4PU, Sage Publication Ltd 6 Benhill Street.

Sodik, Mochmmad. 2006. "Pendekatan Sosologi" dalam Dudung Abdurrahman (ed.) Metodologi Penelitian Agama. Yogyakarta: Kurnia Kalam Semesta.

Strauss, Anselm dan Corbin, Juliet, 2007. Dasar-dasar Penelitian Kualitatif; Tata Langkah dan Teknik-teknik Teoritisasi Data. Yogyakarta: Pustaka Pelajar. 
Suprayogo, Imam \& Tabrani. 2003. Metodologi Penelitian Sosial Agama. Bandung: Rosda Karya.

Sutopo, Harbertus. 1998. Pengantar Penelitian Kualitatif: Dasar-dasar Teoretis dan Praktis. Surakarta: Pusat Penelitian UNS.

Tarrow, Sydney, 1998. Power In Movement Social Movement and Contentious Politics. Cambridge: Cambridge University Press. 